\title{
Personality and methods of coping with stress
}

\section{Osobowość a sposoby radzenia sobie ze stresem}

\author{
Aleksandra Cieślik \\ Department of Circulatory System Diseases and Prevention, Institute of Public Health, Faculty of Health Science, Jan Kochanowski \\ University, Kielce, Poland \\ Director of Department: Prof. Beata Wożakowska-Kapłon MD, aPhD
}

Studia Medyczne 2014; 30 (1): 57-60

Key words: stress, personality, ways of coping.

Słowa kluczowe: stres, osobowość, sposoby radzenia sobie.

\begin{abstract}
Good health and well-being are the natural desires of every human being. However, people have to cope with various kinds of stress in everyday life. Most people are under stress due to: the situation in the world, unemployment, traffic jam, their manager's opinion, illness, divorce, etc. The level of stress increases particularly in situations when people sense danger of physical, social or psychological risks. This phenomenon is very common, and many people have come to think that this is something normal in modern life. Stress can cause depression and frustration, and it does not help in achieving goals and being successful. Ordinary people have a negative concept of stress, but stress response also helps one to rise to meet challenges. Some level of stress is recommended because it helps people to solve problems. While under stress one can function better and work faster, it sharpens concentration and increases brain efficiency. At the beginning of the third millennium, stress has become the people's enemy, so they should learn how to cope with it. It is common knowledge that one cannot avoid stress, so it is important to learn how to control and deal with it.
\end{abstract}

\section{Streszczenie}

Naturalnym pragnieniem człowieka jest życie w dobrym zdrowiu i samopoczuciu. Tymczasem każdy często jest poddawany różnego rodzaju stresom. Ludzie stresują się prawie wszystkim: wydarzeniami na świecie, bezrobociem, korkiem na ulicy, spojrzeniem przełożonego, chorobą, rozwodem. Poziom stresu zwiększa się szczególnie w sytuacjach, gdy istnieje poczucie zagrożenia fizycznego, społecznego lub psychicznego. Zjawisko to jest bardzo powszechne i wiele osób uważa, że jest ono typowe dla dzisiejszych czasów. Niejednokrotnie stres jest powodem depresji, frustracji, znacznie rzadziej sojusznikiem w osiąganiu sukcesów i wytyczonych celów. W świadomości przeciętnego człowieka utrwaliło się negatywne pojęcie stresu, ale pomimo że stres wpływa na rozwój wielu chorób, może być także czynnikiem aktywizującym, dopingującym do działania. Pewien poziom stresu jest więc wskazany, dzięki niemu łatwiej rozwiązuje się problemy. Pod wpływem umiarkowanego stresu człowiek może sprawniej funkcjonować, szybciej działać, poprawia się wówczas koncentracja i zwiększa wydajność mózgu. Stres jest poważnym problemem społecznym i zdrowotnym. U progu trzeciego tysiąclecia stres stał się wrogiem publicznym numer jeden, dlatego ludzie powinni nauczyć się nad nim panować. Należy pamiętać, że nie da się uniknąć stresu, dlatego najlepszym wyjściem jest mieć nad nim kontrolę i umieć zaradzić jego skutkom.

\section{Characteristics of stress}

The word "stress" literally means pressure and to tighten. The best-known author regarding the concept of stress is Selye, who said that the organism reacts to various factors (stressors) in the form of "general adaptive symptoms". Selye described this reaction as the stress response, which causes non-specific biological and endocrine changes. An incorrect process of "adapting" may be the cause of various diseases.

Stress is a part of life, and no-one can avoid stress. Scientists and experienced people have been trying to find ways to control stress and cope with it. In modern conceptions of stress, what is especially valuable is that they offer a chance of coping; they suggest that stress is not an independent element of a human in the outside world, but people create stress unconsciously in their minds $[1,2]$.

The classic understanding of stress, although still useful, has many limitations. According to these conceptions, people cannot do much to combat stress. It is impossible to avoid all the negative stimuli, and people have no influence on their physiological responses [2].

Richard Lazarus and Susan Folkman also perceived the above theory; they created their own theory of stress and stress coping. Their conception is the most coherent from the modern psychological theories of stress. 
Contemporary conceptions treat the phenomenon of stress in the categories of people's relation with, or transactions with, their environment. The so-called resources occupy a crucial place in these conceptions; these include knowledge about stress and how to overcome it.

Stress occurs when resources are poor (objectively, or subjectively, it is believed that this is the case) and when the environment around a person is considered as threatening. Being aware of stress management is in some sense equivalent to increasing its resources.

According to Lazarus, especially important resources include the following:

- health (absolute priority),

- high (but adequate) self-esteem,

- friendly social atmosphere (family, friends, colleagues),

- the opportunity to receive help in a given situation,

- knowledge, skills and a good attitude to life [3].

Stress is the result of a dynamic mismatch between an individual's behaviour and their physical or social environment, and disorder of the process of adaptation. From an interactive point of view, the situation itself is not stressful, but the association of a particular situation, and specific mental characteristics and personality traits, generate stress reactions.

The main effect of a stressful situation depends on many conditions:

- the style and way of perceiving the situation,

- own coping skills and social support,

- one's energy and adaptation abilities,

- formation, mental integrity and personality structure,

- the kind of difficult situation,

- the strength of a working stressor,

- the level of health, endurance, and mental and physical resistance [4-6].

\section{What causes stress}

Stress is defined as a set of outer conditions that disrupt the normal functioning of the human organism, negatively affecting the physiological and psychological processes, and disorganising behaviour by reducing the person's efficiency [7]. Taking into account time, strength and requirement, psychologists have divided the stressors that one have to fight with into different groups. Disasters and tragedies are the most dramatic events that come without warning, attacking the person's fundamental values (the meaning of life and security, home) usually leaving a deep mark on the psyche. Some kind of natural disaster, the death of a spouse or loved one are examples of such events, which usually completely change the person and their life. Although the strength of the daily problems and worries is not large, and the range is limited, these stressors can accumulate to the size of serious threats. According to Lazarus, their bad impact is underesti- mated and neglected, and meanwhile common problems of everyday life are the real cause of stress [3].

Research has shown that most people are worried about the following:

- body weight,

- the state of health of a family member,

- increase in prices of consumer goods,

- high job demands,

- a lost item and the impossibility of finding it,

- problems with ownership or taxes,

- crime,

- appearance (e.g. clothes),

- long-lasting accumulation of minor difficulties,

- ignorance, lack of preparation,

- rapid changes,

- lack of solutions - continuously unclear situations,

- blocking of emotions (both positive and negative),

- decision-making.

Career accomplishments (another source of stress) are often associated with increased efforts, the need of constant training, and being the subject of monitoring and evaluation.

A separate group presents the stressors connected with professional development: limited opportunities for horizontal or vertical promotion, dissatisfaction with current job, the threat of job loss, involuntary change of position or place of work and too high or too low qualifications.

Stress can also be caused by workplace conditions: monotony of activities, lack of time, task overload, shifts, technology changes, diversity and huge amount of tasks carried out concurrently.

In general, it can be said that a low level of job satisfaction positively correlates with a decrease in well-being, professional capacity and overall health care [8].

\section{Stages of stress}

1. Alarm stage - this begins with shock, surprise, and general somatic and mental shock and prepares the person to deal with the threat or fight response. At this stage, the following are noticeable: awareness, orientation and evaluation of one's abilities and concentration of energy.

2. Resistance stage - the body adapts to operate in a more extreme situation than the normal mode, periodically becoming resistant to the destructive effects of specific stressors. The essence of mental and biological efforts is the integration and balance, disturbed by the changing environmental requirements. At this stage, a significant decrease in the activity of processes running at the alarm stage is observed.

3. Exhaustion stage - due to prolonged exposure to extreme situations, mechanisms of adaptation are blocked. Again, the body continues in alarm stage mode, activating the endocrine system, trying to adjust to a situation that fails. Energy reserves are depleted. In case of normal energy resources exhaustion, we 
have to deal with a regular disorder of the functional equilibrium of the body. If there is a profound depletion of energy reserves, final and inviolable (difficult to be completed), there is a total, extreme block of body functions, which can lead to serious health problems and extreme complications $[9,10]$.

\section{The clinical picture of stress}

Chronic, intense stress and insufficient anti-stress condition contribute to the onset of the more harmful psychosomatic consequences. These may include severe pathological disorders of most body systems: circulatory, digestive, respiratory and nervous. These are mainly common and troublesome psychosomatic diseases associated with stress, such as: stomach ulcers, duodenal ulcers, colitis, coronary heart disease and hypertension. In addition, stress is one of the factors that increase the risk of diabetes, asthma, rheumatoid arthritis, eczema and allergic ailments. Excessive stress may affect the body in an immunosuppressive way or reduce the immune system's ability to combat a variety of infections, degenerative diseases and even cancer. Other health problems connected with stress are: decrease of sexual drive, sexual dysfunction, abnormal menstrual cycle, hyperventilation of the nervous system, neuralgia of the back, chestand abdomen, dizziness, headache, obstruction and many neurotic disorders and mental illnesses [11, 12].

In case of stage fright, deadlines, lateness for a meeting or other problems (bad news, really difficult situations) there are signs that are very clear and unpleasant, and it is easy to recognise them.

Symptoms of acute stress:

- intense emotional arousal (anger, guilt),

- increased blood pressure,

- increased heart rate,

- tachypnoea,

- dry mouth, weakness in the legs,

- "goose bumps", shaking hands,

- increased blood sugar [13].

\section{Personality and ways of coping with stress}

Basing on several research projects, it can be concluded that a person's personality type has a direct impact on how one can cope with stressful situations and different kinds of stress. Increasingly in the literature, psychology articles describe types of personality using the following system: types A, B, C and D. This typology is not ascribed to any one author, because it is the result of the work of many psychologists who have studied the relationship between personality and ways of coping with stress [11].

\section{Personality type A}

Type A is described as living in a constant rush, doing several things at once. This is typical for some- one who is in pursuit of perfection, and has high expectations and a passion to compete. Type A individuals have problems in relationships with others, resulting from their hostility and dislike. Certain gestures, ways of speaking and movements are also characteristic for this type. Type A is short-tempered and energetic, speaking and walking quickly, interrupting while discussing things, and generally hostile to others. Type A people are unable to relax and they work too much, they even feel guilty while taking a holiday. People with type A personalities are often high-achieving "workaholics", who multitasks, push themselves to meet deadlines, and are intolerant of delays and ambivalence. This is, however, the price to be paid for working at high speed, resulting in a reduction in productivity and, in fact, it causes difficulties rather than helping them to get promoted. The highest price that type A people can pay for success is the loss of their health [11, 14, 15].

\section{Personality type B}

The theory describes type B personalities as being in contrast to type A. Scientists describe this type as "healthy". Regardless of their profession, these types rarely suffer from heart attacks before the age of seventy. Although they are ambitious, they live at a lower stress level and typically work steadily, because quality is much more important for them. Comparing type A with type $B$, it is noticeable that type $B$ experiences less stress while working and relaxing. The theory describes a type B individual as being patient, careful, cooperative, living in a harmony with their environment rather than fighting for a success. Without any problem, these types are in control of their emotions, and others perceive them as friendly and relaxed $[10,11,15]$.

\section{Personality type C}

Type C personality is typical for people who feel dependent on their environment. Type $C$ people feel guilty, showing low social activity, feeling lonely and desolate, they believe that relationships with others can bring them pain and disappointment. This type is represented by patience, a lack of aggressiveness, hidden emotions, submissiveness and unassertiveness. Type C people are vulnerable to others' needs (dedication, excessive altruism). Typical traits for this type include hopelessness, helplessness and pessimism, which can lead to a loss of the will to live [11, 15].

\section{Personality type D}

Type D stands for distress. Type D people have a negative outlook towards life and are pessimistic. The cause of this can be seen in disapproval and being rejected by others. In general, type D are characterised by:

- a tendency to worry, low sense of security,

- pessimistic outlook, 
- the feeling of being unhappy,

- a tendency to blame themselves,

- shyness and poor relationships with other people,

- discomfort in the presence of other people, especially strangers [11].

Type D are famous for suppressing their emotions, and this makes them the most vulnerable type to depression; they have difficulties in the use of social support, low self-esteem, a lack of satisfaction with life and often feel exhausted.

Type D has some similarities to other personality traits; for example, a tendency to hide emotions, as seen in type C. Also characteristic for type $C$ is low awareness of emotions, and type $\mathrm{D}$ individuals deliberately refrain from expressing emotions because of fear of disapproval and rejection. Type D, as a result of stress experienced in the workplace, are characterised by increased risk of professional burnout syndrome, because these people have a low sense of personal achievement and are more emotionally exhausted $[14,15]$.

\section{References}

1. Borkowski J. Radzenie sobie ze stresem. Dom Wydawniczy ELIPSA, Warsaw 2001.

2. Everly G, Rosenfeld R. Stres: przyczyny, terapia i autoterapia. PWN, Warsaw 1992.

3. Lazarus R. Paradygmat stresu i radzenia sobie. Nowiny Psychologiczne, Warsaw 1989; 20-40.

4. Łukasik MI. O stresie inaczej - wykorzystanie modelu synektycznego w edukacji zdrowotnej. Oficyna Wydawnicza „Impuls”, Krakow 2005.

5. Hobfou SE. Stres, kultura i społeczność. Gdańskie Wydawnictwo Psychologiczne, Gdansk 2006.

6. Renard J. Przewodnik antystresowy. Apostrof, Warsaw 1993; 130-139.

7. Heszen-Niejodek I, Ratajczak Z. Stres i radzenie sobie koszty psychologiczne: Człowiek w sytuacji stresu. Wydawnictwo UŚ, Katowice 2000.

8. Wrześniewski K. Style a strategie radzenia sobie ze stresem. Problemy pomiaru. Wydawnictwo UŚ, Katowice 1996.

9. Heszen-Niejodek I, Ratajczak Z. Człowiek w sytuacji stresu. Problemy teoretyczne i metodologiczne. Wydawnictwo UŚ, Katowice 2000.

10. Zawadzki R. Stres - sztuka życia. Wydawnictwo Szkolne i Pedagogiczne, Warsaw 2004.

11. Strelau J. Osobowość a ekstremalny stres. Gdańskie Wydawnictwo Psychologiczne, Gdansk 2005.

12. Terelak JF. Psychologia stresu. Oficyna Wydawnicza Branta, Bydgoszcz 2001.

13. Poprawa R. Zachowania asertywne - czy jest to sposób na stres? Wydział Zarządzania Politechniki Częstochowskiej, Częstochowa 2004

14. Nash W. Jak opanować stres? W stronę pełni. Wydawnictwo „M”, Krakow 1995.

15. Gutmann J. Jak sobie radzić ze stresem? Wydawnictwo JEDNOŚĆ, Kielce 2001.

\section{Address for correspondence:}

Aleksandra Cieślik

Department of Circulatory System Diseases and Prevention Institute of Public Health

Faculty of Health Science

Jan Kochanowski University

al. IX Wieków Kielc 19, 23-317 Kielce, Poland

Phone: +48 603438751

E-mail: alci@onet.com.pl 